\title{
Memperbaiki Serapan Hara dengan Aplikasi Bahan Organik untuk Meningkatkan Resistensi Tanaman Cabai terhadap Virulensi Kutukebul
}

\author{
Improvement Nutrient Uptake with Application of Organic Matter \\ to Increase Resistance of Cayenne Pepper to Whitefly Virulence
}

\author{
Muhammad Helmy Abdillah* \\ Program Studi Budidaya Tanaman Perkebunan, Politeknik Hasnur \\ Jl. Brigjend. H. Hasan Basri, Barito Kuala, Kalimantan Selatan 70582, Indonesia
}

Diterima 3 November 2021/Disetujui 23 Desember 2021

\begin{abstract}
Nutrient balance plays a role in physiological mechanisms. Compost of tea dregs and eggshells powder have been shown to have an effect in providing nutrients but have different abilities, so synergism or antagonism between the compounds may occur. The purpose of this study was to compare the application results of compost from tea dregs and eggshell powder combination on Red-Yellow Podsolic soil to balance NPK and Ca in plant tissue and assess its relationship with plant resistance to whitefly virulence. The benefits of this research is encourage the use of tea dregs and eggshells as soil enhancers. This research was carried out at Polytechnic Hasnur's screen house in April-October 2021 by applying compost from tea dregs and eggshell powder to Red-Yellow Podsolic soil in a cultivation of cayenne pepper of Anjasmara variety. The experiment was arranged in a complete randomized design with Tukey's HSD test at $\alpha=5 \%$. The results showed that the application of $120 \mathrm{~g}$ compost of tea dregs and $40 \mathrm{~g}$ eggshell powder combination increased the percentage of $\mathrm{N}, \mathrm{P}, \mathrm{K}$, and $\mathrm{Ca}$ in plant tissue, thereby encouraging plant resistance to whitefly vector begomovirus virulence. There is a fairly strong and positive relationship of $63 \%$ between nutrients in plant tissues with plant resistance to virulence. The available and balanced nutrients may help plants to form elicitors optimally.
\end{abstract}

Keywords: compost of tea dregs, eggshells powder, elicitors

ABSTRAK

Keseimbangan hara memegang peran dalam mekanisme fisiologis. Ampas teh dan cangkang telur terbukti berpengaruh dalam menyediakan hara namun memiliki kemampuan yang berbeda, sehingga bisa terjadi sinergisme atau antagonisme antar senyawa yang dimilikinya. Tujuan dari penelitian ini yakni membandingkan hasil aplikasi kombinasi kompos ampas teh dan tepung cangkang telur pada tanah Podsolik Merah-Kuning dalam menyeimbangkan NPK dan Ca dalam jaringan tanaman serta menilai hubungannya dengan resistensi tanaman terhadap virulensi kutukebul. Manfaat penelitian ini mendorong penggunaan ampas teh dikomposkan dan cangkang telur dibuat tepung sebagai pembenah tanah. Penelitian ini dilaksanakan di rumah kaca Politeknik Hasnur pada April-Oktober 2021 dengan mengaplikasikan kompos ampas teh dan tepung cangkang telur ke tanah Podsolik Merah-Kuning pada budidaya cabai rawit menggunakan bibit varietas Anjasmara. Penelitian didesain menggunakan rancangan acak lengkap dengan analisis BNJ pada $\alpha=5 \%$. Hasil penelitian menunjukkan pemberian $120 \mathrm{~g}$ kompos ampas teh dikombinasikan $40 \mathrm{~g}$ tepung cangkang pada $10 \mathrm{~kg}$ tanah mampu meningkatkan kadar $\mathrm{N}$, $P, K$, dan Ca dalam jaringan tanaman sehingga mendorong resistensi tanaman terhadap virulensi kutukebul sebagai vektor patogen begomovirus. Terdapat hubungan cukup kuat dan positf sebesar $63 \%$ antara keharaan pada jaringan tanaman dengan resistensi tanaman terhadap virulensi. Keharaan yang tersedia dan seimbang dapat membantu tanaman membentuk elisitor secara optimal.

Kata kunci: elisitor, kompos ampas teh, tepung cangkang telur

\footnotetext{
* Penulis untuk korespondensi. e-mail: abdillah.helmy21@gmail.com
} 


\section{PENDAHULUAN}

Cabai rawit adalah satu diantara komoditas hortikultura yang terus ditingkatkan produksinya. Produksi cabai rawit secara nasional pada tahun 2018 sebesar 1,335.60 ribu ton naik $10.21 \%$ dibandingkan tahun 2017, sedangkan pada tahun 2019 persentasi produksi turun $9.89 \%$ dibandingkan persentasi tahun 2018 yang hanya mencapai 1,374.21 ribu ton (BPS, 2020). Penyebab turunnya produksi diantaranya faktor gagal panen akibat terganggunya kesehatan tanaman karena serangan OPT (Yusuf et al., 2018; Anggraini et al., 2018; Mala et al., 2021). Tanaman cabai rawit sering diserangan hama vektor begomovirus dengan gejala mosaik yang disebabkan virus CMV, TMV dan ChiVMV, bergejala kuning yang diinfeksi oleh PepYLCV dan klorosis yang diinfeksi oleh Polerovirus (Putra et al., 2015; Ferreira et al., 2021).

Kutukebul (Bemisia tabaci Gennadius) merupakan salah satu vektor penyakit begomovirus yang menyebabkan daun tanaman tidak dapat berfotosintesis secara maksimal akibat tertutup embun jelaga, menghasilkan bintik hitam dibawah daun, daun menjadi keriting, kuning dan layu hingga tanaman menjadi kerdil dan mati. Kutukebul merupakan golongan hama yang bersifat polifag dan hidup berkelompok pada ekosistem tanaman rentan secara genetik dengan serapan hara yang tidak optimal. Ditengarai, interaksi kesuburan tanah yang rendah dengan mikro iklim berfluktuatif berpengaruh terhadap populasi kutukebul (Subagyo dan Hidayat, 2014). Tidak berimbangnya serapan hara oleh tanaman diduga menjadi penyebab mudahnya tanaman terserang hama dan terinfeksi penyakit, seperti nitrogen yang berlebihan diduga meningkatkan virulensi patogen melalui mekanisme pelemahan jaringan tanaman akibat lebih aktifnya pertumbuhan tanaman dari kondisi normal (Samota et al., 2017). Ketahanan tanaman terhadap virulensi perlu diusahakan diantaranya dengan memaksimalkan ketahanan genetik dengan mekanisme antixenosis, antibiosis dan toleran (Riti et al., 2018) serta ketahanan ekologis sebagai ketahanan palsu melalui keseimbangan hara (Sopialena, 2017). Interaksi keduanya menghasilkan senyawa elisitor sebagai pertahanan pertama dari cekaman biotik (Andersen et al., 2018; Gowthami, 2018).

Aplikasi bahan organik ditujukan untuk memperbaiki ekosistem, menurunkan toksik, dan menyeimbangkan keharaan sehingga memengaruhi siklus piramida penyakit (Hubber dan Haneklaus, 2007). Menurut Wahjudin (2006) untuk memperbaiki sifat tanah dapat diaplikasikan bahan organik berupa sisa tanaman dan penambahan kapur. Ampas teh dan cangkang telur sebagai bahan organik limbah rumah tangga diyakini mampu menggantikan peran pupuk sintetik dan kapur dolomit untuk menyediakan senyawa hara pada tanah pertanian sehingga mampu memperkuat ketahanan ekologis tanaman dan akhirnya juga berpengaruh pada optimalisasi ketahanan genetik. Shaban et al. (2015) melaporkan bahwa kompos ampas teh dapat memperbaiki dinamika senyawa kimia tanah mineral karena mengandung asam-asam organik dan unsur hara esensial. Selain itu, penelitian terhadap cangkang telur mampu meningkatkan ketersediaan Ca dan pH tanah (Khairnar dan Nair, 2021).

Ketersediaan hara juga meningkatkan resistensi tanaman dari virulensi patogen dengan optimalisasi serapan dan penggunaan hara yang efisien, peningkatan metabolisme, dan pembentukan elisitor (Gupta et al., 2017; Jamiolkowska, 2020). Keseimbangan unsur hara dan pengkayaan bahan organik secara tepat mampu mengendalikan cekaman biotik sehingga tanaman menghasilkan senyawa elisitor yang optimal (Blundell et al., 2020; Tahat et al., 2020). Dari latar belakang tersebut, diharapkan kombinasi kompos ampas teh dan tepung cangkang telur dapat mengoptimalkan penyediaan unsur hara esensial sehingga dapat meningkatkan resistensi tanaman dari virulensi. Tujuan dari penelitian ini yakni membandingkan hasil aplikasi kombinasi kompos ampas teh dan tepung cangkang telur pada tanah Podsolik Merah-Kuning dalam menyeimbangkan kadar N, P, K, dan $\mathrm{Ca}$ dalam jaringan tanaman serta menilai hubungannya dengan resistensi tanaman terhadap virulensi kutukebul. Manfaat penelitian ini mendorong penggunaan ampas teh dan cangkang telur sebagai pembenah tanah dan lebih luas berperan dalam pembentukan elisitor pengendalian virulensi OPT.

\section{BAHAN DAN METODE}

Penelitian ini dilakukan dari April sampai dengan Oktober 2021 yang dilakukan di rumah kaca Politeknik Hasnur, Kabupaten Barito Kuala, Kalimantan Selatan. Persiapan penelitian dilakukan dengan mengumpulkan ampas teh dan cangkang telur diwilayah Kelurahan Handil Bakti. Pengomposan ampas teh dengan metode aerobik yang ditambahkan cairan yang mengandung mikroorganisme lokal dari campuran bonggol pisang dengan air leri (Inrianti et al., 2019) kemudian dicampurkan merata sebanyak $50 \mathrm{~mL} \mathrm{~kg}^{-1}$ pada ampas teh, sedangkan cangkang telur berasal dari berbagai telur unggas (ayam dan itik) yang digiling hingga teksturnya halus seperti tepung. Bahan ini mengandung $\mathrm{CaCO}_{3}$ yang sangat tinggi mencapai 92\% (Ajayan et al., 2020). Bahan tanam yang digunakan yakni cabai rawit varietas Anjasmara yang bersertifikasi label ungu, karena menurut penelitian (Angreani, 2018; Zulfidah, 2018) mengujicoba beberapa varietas unggul cabai rawit menemukan bahwa varietas Anjasmara rentan serangan jenis kutu daun.

Penanaman benih dimulai dengan menyemai benih pada media tanah yang dicampur kompos ampas teh. Pemindahan tanaman ke polibag utama dilakukan pada saat benih telah menjadi bibit tanaman cabai yang menunjukkan minimal 3 daun terbuka sempurna. Bibit dipindah ke polibag utama yang berukuran $25 \mathrm{~cm} \times 30 \mathrm{~cm}$ dan telah berisi tanah Podsolik Merah-Kuning seberat $10 \mathrm{~kg}$ dengan kombinasi kompos ampas teh dan tepung cangkang telur yang sudah diaplikasikan 21 hari sebelumnya dengan taraf dosis sesuai perlakuan. Setelah pindah tanam, tanaman disiram dengan air buangan $\mathrm{AC}$ sebanyak $100 \mathrm{~mL}$ pada setiap pagi dan sore. Penggunaan air buangan AC dilakukan karena meminimalisir kontaminasi fisika, kimia dan biologi yang berpotensi memengaruhi hasil penelitian. Tiswan dan Ramlan (2018) 
melaporkan bahwa air buangan AC memiliki kontaminan yang sangat rendah dan berpotensi menggantikan akuades (Samik et al., 2017).

Introduksi kutukebul dilakukan dengan cara mencari tanaman cabai rawit yang sudah terserang dengan gejala akut di kawasan agrowisata hortikultura Kecamatan Landasan Ulin, Kalimantan Selatan. Kriteria tanaman cabai rawit tersebut menunjukkan daun yang kuning layu, penuh embun jelaga pada setiap bagian bawah helai daun dengan intensitas kerusakan $>60 \%$. Infeksi hama kutukebul tersebut dilakukan dengan cara meletakkan 5 tanaman yang terserang di 4 sudut dan 1 bagian tengah di area percobaan dengan jarak $200 \mathrm{~cm}$ dari tanaman penelitian pada hari ke30 setelah pindah tanam dengan diacak.

\section{Rancangan Percobaan dan Pengamatan Peubah}

Penelitian ini didesain menggunakan Rancangan Acak Lengkap (RAL) faktorial yakni jenis bahan dan taraf dosis. Aplikasi kompos ampas teh per polibag dengan 3 taraf dosis yakni $0 \mathrm{~g}, 60 \mathrm{~g}, 120 \mathrm{~g}$, dan aplikasi tepung cangkang telur per polibag dengan 3 taraf dosis yaitu $0 \mathrm{~g}, 40 \mathrm{~g}, 80$ g, didapatkan 9 kombinasi perlakuan yang diulang 4 kali sehingga terdapat 36 satuan percobaan.

Pengamatan peubah dalam penelitian ini dilakukan terhadap nilai resistensi tanaman serta kadar N, P, K, dan $\mathrm{Ca}$ pada jaringan tanaman. Penetapan resistensi dihitung pada semua satuan percobaan saat tanaman berumur 70 hari setelah tanam. Perhitungan resistensi (R) tanaman dilakukan dengan prinsip scrining secara matematis menggunakan rumus (CIAT, 2005) yang dimodifikasi:

$$
\mathrm{R}(\%)=100-\left(\frac{\sum n i \times v i}{N \times Z}\right)
$$

dimana, $\mathrm{R}=$ resistensi (\%) yang dikonversi ke dalam klasifikasi pada Tabel 1, 100 adalah nilai mutlak ketahanan tanaman, $n i=$ jumlah daun tanaman yang diamati pada skala kerusakan, $v i=$ skala prediksi hasil pengamatan kerusakan akibat serangan hama, $N=$ jumlah tanaman yang diamati, $Z=$ indeks skala kerusakan tertinggi yang terdapat dalam lingkup percobaan tersebut sesuai pada Tabel 2 .

Analisis keharaan jaringan tanaman dilakukan pada 80 hst dengan mencabut semua tanaman satuan percobaan dari tanah kemudian dari masing-masing satuan tanaman percobaan diambil secara acak terhadap 3 daun yang paling rusak, 3 daun yang paling sehat, $3 \mathrm{~cm}$ batang bagian tengah dan $3 \mathrm{~cm}$ batang bagian ranting, kemudian dibasuh perlahan

Tabel 1. Resistensi tanaman dalam toleransi terhadap serangan hama dan penyakit

\begin{tabular}{ll}
\hline Persentase (\%) & Klasifikasi resistensi \\
\hline $\mathrm{R} \leq 25$ & Buruk \\
$\mathrm{R}=25-\leq 50$ & Cukup buruk \\
$\mathrm{R}=>50-80$ & Sedang \\
$\mathrm{R}=>80-90$ & Baik \\
$\mathrm{R}=>90-100$ & Sangat baik \\
\hline
\end{tabular}

dengan air mengalir hingga bersih dari debu, tanah dan embun jelaga. Sampel tanaman dikering-anginkan dalam desikator kemudian dioven pada suhu $70^{\circ} \mathrm{C}$ selama 8 jam lalu digiling halus $(0.5 \mathrm{~mm})$ menjadi satu dan diambil sampel $0.5 \mathrm{~g}$ yang selanjutnya dilakukan analisis keharaan jaringan dengan metode pengabuan basah menggunakan pereaksi $\mathrm{H}_{2} \mathrm{SO}_{4}$ untuk analisis $\mathrm{N}$, sedangkan untuk analisis $\mathrm{P}, \mathrm{K}$, dan $\mathrm{Ca}$ menggunakan pereaksi $\mathrm{HNO}_{3}$ dan $\mathrm{HClO}_{4}$ dengan mengukur gelombang cahaya menggunakan spektrofotometer (BPT, 2009).

\section{Analisis Data}

Analisis data menggunakan SPSS 25, didahului uji normalitas dan homogenitas menggunakan model ShapiroWilk dan uji Bartlett. Apabila nilai memenuhi persyaratan terdistribusi normal dan homogen maka dilanjutkan dengan analisis ragam (ANOVA). Apabila perlakuan berpengaruh nyata maka dilanjutkan dengan uji beda nilai tengah menggunakan metode BNJ pada $\alpha=5 \%$. Hubungan antara keharaan jaringan tanaman dengan resistensi tanaman dapat uji dengan analisis regresi-korelasi linier berganda secara matematis (Paiman, 2019):

$$
\begin{gathered}
Y_{i}=b_{0}+b_{1} X_{1}+b_{2} X_{2}+\ldots+b_{k} X_{k} \ldots \ldots \ldots \\
r_{Y_{-} X_{1} X_{2}}=\sqrt{\frac{r^{2} X_{1} Y+r^{2} X_{2} Y-2\left(r X_{1} Y \times r X_{2} Y \times r X_{1} X_{2}\right)}{1-r^{2} X_{1} X_{2}}} \ldots \ldots \ldots
\end{gathered}
$$

\section{HASIL DAN PEMBAHASAN}

\section{Kadar NPK dan Ca Jaringan Tanaman}

Hasil uji ragam rerata kadar $\mathrm{N}$ pada Tabel 3 menunjukkan aplikasi kombinasi $120 \mathrm{~g}$ kompos ampas teh dan $80 \mathrm{~g}$ tepung cangkang telur memberikan hasil tertinggi kadar hara $\mathrm{N}$ pada jaringan tanaman, namun tidak berbeda nyata dibandingkan kadar $\mathrm{N}$ jaringan tanaman pada aplikasi kombinasi $120 \mathrm{~g}$ kompos ampas teh dan $40 \mathrm{~g}$ tepung cangkang telur, hal ini mungkin disebabkan adanya sinergisme bahan yang dikombinasikan pada dosis tertentu sehingga serapan dan endapan $\mathrm{N}$ pada jaringan tanaman dari perlakuan tersebut tidak berbeda nyata.

Kadar P jaringan tanaman (Tabel 4) tertinggi terdapat pada perlakuan kombinasi 120 g kompos ampas teh dan 40 g tepung cangkang telur dan berbeda nyata dibandingkan perlakuan lain. Kadar K (Tabel 5) tertinggi pada jaringan tanaman terdapat pada kombinasi $120 \mathrm{~g}$ kompos ampas teh dan $0 \mathrm{~g}$ tepung cangkang telur namun tidak berbeda nyata dengan kombinasi $120 \mathrm{~g}$ kompos ampas teh dan $40 \mathrm{~g}$ tepung cangkang telur, sedangkan kadar Ca tertinggi terdapat pada jaringan tanaman yang diberi perlakuan $0 \mathrm{~g}$ kompos ampas teh dan $80 \mathrm{~g}$ cangkang telur, namun tidak berbeda nyata dengan kombinasi $120 \mathrm{~g}$ kompos ampas teh dan $80 \mathrm{~g}$ tepung cangkang telur maupun $40 \mathrm{~g}$ tepung cangkang telur (Tabel $6)$.

Eudoxie dan Martin (2019) menyatakan asam organik pada kompos ampas teh dapat menyediakan $\mathrm{N}$, P, dan $\mathrm{K}$ 
Tabel 2. Skala kerusakan tanaman

\begin{tabular}{llll}
\hline Skala $(\mathrm{Z})$ & Persentase $(\%)$ & Kriteria & \multicolumn{1}{c}{ Gejala } \\
\hline 0 & $\mathrm{x}=0$ & Normal & Tidak ada kerusakan \\
1 & $0<\mathrm{x} \leq 25$ & Rusak ringan & $5-25 \%$ Daun kuning, mulai layu \\
2 & $25 \mathrm{x} \leq 50$ & Rusak sedang & $>25 \%$ Daun kuning, keriting, layu \\
3 & $50<\mathrm{x} \leq 75$ & Rusak berat & $>50 \%$ Daun kuning, keriting dan pertumbuhannya melambat \\
4 & $\mathrm{x}>75-100$ & Sangat berat & $>75 \%$ Tanaman layu, kerdil, kering \\
\hline
\end{tabular}

dengan mekanisme melepas khelat dengan logam dan memicu kinerja mikroorganisme penghasil $\mathrm{N}$, sedangkan peran tepung cangkang telur menyediakan Ca yang berfungsi seperti kapur (Sitohang et al., 2020), sedangkan mekanisme fisiologis terhadap ketahanan patogen erat kaitannya dengan pembentukan elisitor diantaranya phytoalexin senyawa sesquiterpene seperti capsidiol khususnya pada tanaman cabai (Capsicum annuum) (Arruda et al., 2016; Guest, 2017), yang terbentuk dari sintesis senyawa hara yang diserap tanaman seperti Ca dan N (Zhong, 2011).

Pada penelitian ini terlihat bahwa pemberian tepung cangkang telur yang semakin tinggi menunjukkan kecenderungan semakin tinggi pula endapan $\mathrm{Ca}$ pada jaringan tanaman yang justru membuat turunnya kadar $\mathrm{P}$ dan $\mathrm{K}$ dalam jaringan, hal ini disebabkan oleh sifat antagonisme antara kation Ca dan K, Ca dan P maupun dengan N (Rietra et al., 2017; Rhodes et al., 2018), ketersediaan hara pada koloid tanah berbanding lurus dengan indeks serapan hara dan kadar senyawa hara di dalam jaringan tanaman (Ogidi et al., 2018; Etienne et al., 2018). Penelitian Olego et al. (2021) menunjukkan tingkat pengapuran yang tinggi pada tanah tipe Palexerult berpengaruh terhadap kandungan $\mathrm{Ca}$ pada jaringan tanaman gandum hitam.

\section{Hubungan Hara pada Jaringan Tanaman dengan Resistensi Tanaman}

Pada Tabel 7 menunjukkan resistensi tertinggi tanaman terlihat dari aplikasi kombinasi $120 \mathrm{~g}$ kompos ampas teh dengan $80 \mathrm{~g}$ tepung cangkang telur namun tidak berbeda nyata dengan $120 \mathrm{~g}$ kompos ampas teh yang dikombinasikan $40 \mathrm{~g}$ tepung cangkang telur, hal ini disebabkan ketersediaan hara makro dan mikro yang telah terpenuhi dengan mekanisme pertukaran kapasitas kation dan retensi logam oleh asam organik yang berjalan optimal dari bahan yang diberikan, sedangkan nilai resistensi yang paling rendah terlihat pada tanaman yang diberi perlakuan $0 \mathrm{~g}$ kompos ampas teh dan tepung cangkang telur yang disebabkan oleh kapasitas keharaan yang rendah.

Ketersediaan unsur hara di dalam tanah dan hara yang diserap oleh tanaman memiliki peran besar terhadap berlangsungnya fase-fase kehidupan tanaman. Hubungan antara ketersediaan nutrisi, resistensi serangan hama dan penyakit tanaman sangat erat kaitannya (Weinmann et al., 2012). Pada berbagai tanaman, stress akibat kelebihan ataupun kekurangan hara berdampak pada ketahanan tanaman terhadap virulensi. Seringkali rendahnya keharaan

Tabel 3. Rerata kadar hara $\mathrm{N}$ dalam jaringan tanaman (\%) berdasarkan perlakuan yang diaplikasikan

\begin{tabular}{lccc}
\hline Dosis kompos ampas teh & \multicolumn{3}{c}{ Dosis cangkang telur (g per polibag) } \\
\cline { 2 - 4 } (g per polibag) & 0 & 40 & 80 \\
\hline 0 & $0.45 \mathrm{c}$ & $0.40 \mathrm{c}$ & $0.51 \mathrm{bc}$ \\
60 & $0.53 \mathrm{bc}$ & $0.67 \mathrm{~b}$ & $0.68 \mathrm{~b}$ \\
120 & $0.61 \mathrm{~b}$ & $0.74 \mathrm{a}$ & $0.75 \mathrm{a}$ \\
\hline
\end{tabular}

Keterangan: Angka yang diikuti oleh huruf yang sama tidak berbeda nyata berdasarkan uji BNJ pada taraf $\alpha=5 \%$

Tabel 4. Rerata kadar hara P dalam jaringan tanaman (\%) berdasarkan perlakuan yang diaplikasikan

\begin{tabular}{lccc}
\hline Dosis kompos ampas teh & \multicolumn{3}{c}{ Dosis cangkang telur (g per polibag) } \\
\cline { 2 - 4 } (g per polibag) & 0 & 40 & 80 \\
\hline 0 & $0.17 \mathrm{c}$ & $0.23 \mathrm{c}$ & $0.15 \mathrm{c}$ \\
60 & $0.19 \mathrm{c}$ & $0.32 \mathrm{~b}$ & $0.28 \mathrm{bc}$ \\
120 & $0.29 \mathrm{bc}$ & $0.45 \mathrm{a}$ & $0.32 \mathrm{~b}$ \\
\hline
\end{tabular}

Keterangan: Angka yang diikuti oleh huruf yang sama tidak berbeda nyata berdasarkan uji BNJ pada taraf $\alpha=5 \%$ 
Tabel 5. Rerata kadar hara K dalam jaringan tanaman (\%) berdasarkan perlakuan yang diaplikasikan

\begin{tabular}{lccc}
\hline Dosis kompos ampas teh & \multicolumn{3}{c}{ Dosis cangkang telur (g per polibag) } \\
\cline { 2 - 4 } (g per polibag) & 0 & 40 & $0.21 \mathrm{c}$ \\
\hline 0 & $0.19 \mathrm{c}$ & $0.33 \mathrm{bc}$ & $0.44 \mathrm{~b}$ \\
60 & $0.57 \mathrm{~b}$ & $0.60 \mathrm{~b}$ & $0.58 \mathrm{~b}$ \\
120 & $0.78 \mathrm{a}$ & $0.75 \mathrm{a}$ & \\
\hline
\end{tabular}

Keterangan: Angka yang diikuti oleh huruf yang sama tidak berbeda nyata berdasarkan uji BNJ pada taraf $\alpha=5 \%$

Tabel 6. Rerata kadar hara Ca dalam jaringan tanaman (\%) berdasarkan perlakuan yang diaplikasikan

\begin{tabular}{lccc}
\hline $\begin{array}{l}\text { Dosis kompos ampas teh } \\
\text { (g per polibag) }\end{array}$ & \multicolumn{3}{c}{ Dosis cangkang telur (g per polibag) } \\
\cline { 2 - 4 } & 0 & 40 & 80 \\
\hline 0 & $0.11 \mathrm{c}$ & $0.48 \mathrm{~b}$ & $0.83 \mathrm{a}$ \\
60 & $0.32 \mathrm{bc}$ & $0.52 \mathrm{~b}$ & $0.80 \mathrm{a}$ \\
120 & $0.29 \mathrm{c}$ & $0.65 \mathrm{ab}$ & $0.74 \mathrm{a}$ \\
\hline
\end{tabular}

Keterangan: Angka yang diikuti oleh huruf yang sama tidak berbeda nyata berdasarkan uji BNJ pada taraf $\alpha=5 \%$

menjadi sebab turunnya imunitas dan daya pulih tanaman (Val-Torregrosa et al., 2021). Oleh sebab itu keberimbangan hara, serapan hara, dan efesiensi penggunaan hara sangat penting untuk mengahadapi cekaman biotik tersebut (Gull et al., 2019). Perlakuan dengan dosis kombinasi kompos ampas teh dan tepung cangkang telur pada taraf dosis tertentu menyebabkan tanaman kekurangan senyawa hara maupun kelebihan senyawa lain yang sebenarnya hanya sedikit diperlukan oleh tanaman.

Pada tanah dengan dominasi $\mathrm{Fe}$ tinggi dapat mengganggu pertumbuhan dan metabolisme tanaman (Effendi et al., 2015), namun senyawa Fe yang dapat dikendalikan dengan perlakuan kompos ampas teh dan tepung cangkang telur mampu berperan sebagai kofaktor enzim dalam pembentukan kloroplas dan transfer elektron pada proses respirasi (Rout dan Sahoo, 2015). Selain itu pengaruh positif dari aplikasi kompos ampas teh dan tepung cangkang telur dapat meningkatkan ketersediaan senyawa $\mathrm{N}$ pada kadar yang optimal. Menurut Sun et al. (2020) senyawa N merupakan bahan utama pembentukan senyawa phytoalexin yang berperan sebagai elisitor dengan memengaruhi pertahanan lokal sehingga membentuk resistensi sistemik seperti membentuk ekspresi gen terkait pertahanan awal melalui regulasi nitrat serta sebagai kofaktor enzim dari senyawa lainnya, namun apabila senyawa $\mathrm{N}$ terlalu tinggi dapat melemahkan dinding sel, terjadinya antagonisme terhadap senyawa lain yang juga berperan dalam pembentukan phytoalexin dan lebih aktifnya pertumbuhan vegetatif dapat mendorong suasana mikro iklim yang nyaman bagi hama vektor untuk mempermudah virulensinya.

Hasil uji berganda pada Tabel 8 menunjukkan hubungan yang cukup kuat dengan arah positif antara senyawa hara pada jaringan tanaman dengan resistensi tanaman terhadap virulensi kutukebul sebesar $63 \%$ dengan probabiliti $<0.05$. Menurut Hu et al. (2020) interaksi nutrisi dengan serangan patogen tidak dapat dijelaskan secara utuh karena sifatnya yang kompleks dan tergantung pada sejumlah faktor eksternal lain. Toksisitas logam maupun ketidakseimbangan hara akan memengaruhi kerentanan terhadap virulensi yang disebabkan abnormalnya fungsi morfologis dan fisiologis tanaman, terutama yang berkaitan dengan penyerapan nutrisi, asimilasi, translokasi, dan pemanfaatannya (Dordas, 2008; Bala et al., 2018; Belete, 2018), sehingga terdapat disintegrasi signal imunitas yang disebabkan cekaman biotik dan abiotik (Saijo dan Loo, 2019).

Tabel 7. Rerata resistensi tanaman (\%) yang diserang kutukebul berdasarkan perlakuan yang diaplikasikan

\begin{tabular}{lccc}
\hline Dosis kompos ampas teh & \multicolumn{3}{c}{ Dosis cangkang telur (g per polibag) } \\
\cline { 2 - 4 } (g per polibag) & 0 & 40 & 80 \\
\hline 0 & $11.3 \mathrm{~d}$ & $42.3 \mathrm{c}$ & $45.2 \mathrm{c}$ \\
60 & $53.3 \mathrm{c}$ & $71.8 \mathrm{~b}$ & $78.3 \mathrm{~b}$ \\
120 & $67.7 \mathrm{bc}$ & $90.4 \mathrm{a}$ & $91.8 \mathrm{a}$ \\
\hline
\end{tabular}

Keterangan: Angka yang diikuti oleh huruf yang sama tidak berbeda nyata berdasarkan uji BNJ pada taraf $\alpha=5 \%$ 
Tabel 8. Hubungan berganda kadar hara pada jaringan tanaman $(\mathrm{N}, \mathrm{P}, \mathrm{K}$, dan $\mathrm{Ca})$ dengan resistensi tanaman cabai rawit dari serangan kutukebul

\begin{tabular}{lc}
\hline \multicolumn{2}{c}{ Nilai koefisien } \\
\hline Koefisien determinasi & $0.631^{*}$ \\
Persamaan regresi & $\mathrm{Y}=-0.472+0.293 \mathrm{X}_{1}+0.193 \mathrm{X}_{2}$ \\
& $+0.227 \mathrm{X}_{3}+0.117 \mathrm{X}_{4}$ \\
\hline
\end{tabular}

Keterangan: *nyata pada nilai $\mathrm{p}<0.05$

\section{KESIMPULAN}

Dibandingkan perlakuan lain, kombinasi $120 \mathrm{~g}$ kompos ampas teh dengan $40 \mathrm{~g}$ tepung cangkang telur mampu meningkatkan kadar $\mathrm{N}, \mathrm{P}, \mathrm{K}$, dan $\mathrm{Ca}$ jaringan tanaman sehingga mendorong hubungan positif dan cukup kuat sebesar $63 \%$ terhadap resistensi tanaman dari virulensi kutukebul sebagai vektor begomovirus.

\section{DAFTAR PUSTAKA}

Ajayan, N., K.P. Shahanamol, A.U. Arun, S. Soman. 2020. Quantitative variation in calcium carbonate content in shell of different chicken and duck varieties. J. Adv. Zool. Bot. 8:1-5. Doi: https://doi.org/10.13189/ azb.2020.080101.

Andersen, E.J., S. Ali, E. Byamukama, Y. Yen, M.P. Nepal. 2018. Disease resistance mechanisms in plants. J. Genes. 9:339. Doi:https://doi.org/10.3390/ genes 9070339 .

Anggraini, K., K.A. Yuliadhi, D. Widaningsih. 2018. Pengaruh populasi kutu daun pada tanaman cabai besar (Capsicum annuum L.) terhadap hasil panen. J. Agroekoteknologi Tropika. 7:113-121.

Angreani, Y. 2018. Pengaruh varietas dan jarak tanam terhadap populasi kutukebul Bemisia tabaci Genn pada Capsicum frutescens Linn. Skripsi. Departemen Hama dan Penyakit Fakultas Pertanian. Universitas Hasannuddin. Makassar.

Arruda, R.L., A.T.S. Paz, M.T.F. Bara, M.V. de Carvalho, M.C.C. de Filippi, E.C. da Conceico. 2016. An Approach on phytoalexins: fungtion, characterizations and biosynthesis in plants of the family Poaceae. Bio. Sci. Rural. 46:1206-1216. Doi:https://doi. org/10.1590/0103-8478cr20151164.

BPS [Badan Pusat Statistik]. 2020. Statistik hortikultura. p. 20-23 . In Setiawati, R., Sulistina, R. Widyastuti, T.H. Marpung, M. Ulum (Eds.). Statistik Tanaman Pangan, Hortikultura, dan Perkebunan. BPS-Statistik, Jakarta, Indonesia.
BPT [Balai Penelitian Tanah]. 2009. Analisis jaringan tanaman. p. 96-105. In Prasetyo, B.H, D. Santoso, L. Retno (Eds.). Analisis kimia tanah, tanaman, air dan pupuk. Balai Penelitian Tanah, Bogor. Indonesia.

Bala, K., A.K. Sood, V.S. Pathania, S. Thakur. 2018. Effect of plant nutrition in insect pest management. J. Pharmacogn. Phytochem. 7:2737-2742.

Belete, T. 2018. Defense mechanisms of plants to insect pests: from morphological to biochemical approach. J. Trends Tech. Sci. Res. 2:30-39. Doi:https://doi. org/10.19080/ttsr.2018.02.555584.

Blundell, R., J.E. Schmidt, A. Igwe, A.L. Cheung, R.L. Vannette, A.C.M. Gaudin, C.L. Casteel. 2020. Organic management promotes natural pest control through altered plant resistance to insects. J. Nature Plants. 6:483-491. Doi:https://doi.org/10.1038/ s41477-020-0656-9.

[CIAT] Centro Internacional de Agricultura Tropical. 2005. Whitefly and Whitefly-borne Viruses in The Tropics. p. 203-229. In Anderson, P.K, F.J. Morales, A.L, Jones, R.H. Markham (Eds.). Building a Knowledge Base for Global Action for Whitefly. CIAT Press, Valle del Cauca, CO.

Dordas, C. 2008. Role of nutrients in controlling plant diseases in sustainable agriculture. A review. J. Agron. Sustain. Dev. 28:33-46. Doi:https://doi.org/10.1051/ agro:2007051.

Effendi, M.I., P. Cahyono, B. Prasetya. 2015. Pengaruh toksisitas besi terhadap pertumbuhan dan hasil biomassa pada tiga klon tanaman nanas. J. Tanah Sumberdaya Lahan 2:179-189.

Etienne, P., S. Diquelou, M. Prudent, C. Salon, A. Maillard, A. Ourry. 2018. Macro and micronutrient storage in plant and their remobilization when facing scarcity: The case of drought. J. Agric. 14:2-17. 4; Doi: https:// doi.org/10.3390/agriculture8010014.

Eudoxie, G., M. Martin. 2019. Compost Tea Quality and Fertility. In M.L. Larramendy, S. Soloneski $(E d s$.$) . Organic Fertilizers: History, Production and$ Applications. Intechopen: 1016. Doi:https://doi. org/10.5772/intechopen.86877.

Ferreira, M.A., R.M. Teixeira, E.P.B. Fontes. 2021. Gemini virus-host interactions: action and reaction in receptor-mediated antiviral immunity. J. Viruses 840:1-11. Doi: https://doi.org/10.3390/v13050840. 
Gowthami, L. 2018. Role of elicitors in plant defense mechanism. J. Pharmacogn. Phytochem. 7:28062812.

Guest, D.I. 2017. Phytoalexins, natural plant protection. J. Int. Ency. Appl. Plant Sci. 3:124-128. Doi:https://doi. org/10.1016/B978-0-12-394807-6.00062-9.

Gull,A.,A. Lone., N. U1 Islam-Wani. 2019. Biotic and Abiotic Stress in Plant. In De-Oliveira, A (Eds.). Intechopen, Doi:https://doi.org/10.5772/intechopen.85832.

Gupta, N., S. Debnath, S. Sharma, P. Sharma, J. Purohit. 2017. Role of nutrients in controlling the plant diseases in sustainable agriculture. In Meena. V.S., J.K Bisht, P.K. Mishra, A. Pattanayak (Eds). Agriculturally Important Microbes for Sustainable Agriculture. Springer Singapore. Doi.org/10.1007/978-981-105343-6 8.

Hu, L., J. Wang, C. Yang, F. Islam, H.J. Bouwmeester, S. Munos, W. Zhou. 2020. The effect of virulence and resistance mechanisms on the interactions between parasitic plant and their hosts. Int. J. Mol. Sci. 21: 127. Doi:https://doi.org/10.3390/ijms21239013.

Huber, D.M., S. Haneklaus. 2007. Managing nutrition to control plant disease. J. Landbauforscung Volkenrode. 57:313-322.

Inrianti, S. Tuhuteru, S. Paling. 2019. Pembuatan mikroorganisme lokal bonggol pisang pada kelompok tani tunas harapan Distrik Walelagama, Jayawijaya, Papua. J. Pengabdian kepada Masyarakat. 5:188-194. Doi:https://doi.org/10.29244/agrokreatif.5.3.188194.

Jamiolkowska, A. 2020. Natural compounds as elicitors of plant resistance against diseases and new biocontrol strategies. Agronomy 173:1-11. Doi:https://doi. org/10.3390/agronomy10020173.

Khairnar, M.D., S.S. Nair. 2021. Study on eggshell and fruit peels as a fertilizer. Int. J. Innov. Eng. Res. Tecno. $8: 25-27$.

Mala, N., F.E. Prasmatiwi, W.D. Sayekti. 2021. Pendapatan dan resiko usaha tani di Kecamatan Sumberejo Kabupaten Tanggamus. J. Agribuss. Sci. 9:91-98.

Ogidi, E.G.O., I.K. Okore, J.C. Dike. 2018. Correlation analysis of nutrient soil-plant content and bud take success in Hevea brasiliensis Muell. Arg. in acid soil of South Eastern Nigeria. J. Exp. Bio. Agr. Sci. 6:116-123. Doi:http://dx.doi.org/10.18006/2018.6(1) .116 .123
Olego, M.Á., M.J. Quiroga, C. Mendaña-Cuervo, J. CaraJiménez, R. López, E. Garzón-Jimeno. 2021. Longterm effects of calcium-based liming materials on soil fertility sustainability and rye production as soil quality indicators on a typic Palexerult. J. Processes 9:2-18. Doi:https://doi.org/10.3390/pr9071181.

Paiman. 2019. Teknik Analisis Korelasi dan Regresi IlmuIlmu Pertanian in Dwipa, N.N (Eds.). Universitas Pendidikan Yogyakarta Press. Yogyakarta.

Putra, I., N. Puspawati, I. Nyana, I. Siadi, G. Suastika. 2015. Identifikasi virus yang berasosiasi dengan penyakit mosaik, kuning dan klorosis pada tanaman cabai rawit (Capsicum frutescens L.) J. Tropical Agroecotechnology 4:244-252.

Rhodes, R., N. Miles, J.C. Hughes. 2018. Interactions between potassium, calcium and magnesium in sugarcane grown on two contrasting soils in South Africa. J. Field Crops Res. 225:180. Doi:https://doi. org/10.1016/j.fcr.2018.01.001.

Rietra, R.P., M. Heinen, C.O. Dimkpa, P.S. Bindraban. 2017. Effects of nutrient antagonism and synergism on yield and fertilizer use efficiency. Comm. Soil Sci. Plant. 48:1895-1920. Doi:https://doi.org/10.1080/00 103624.2017.1407429.

Riti, E., M. Syukur, A. Maharijaya, P. Hidayat. 2018. Keragaman genetik 19 genotipe cabai rawit merah (Capsicum frutescens) serta ketahanannya terhadap kutu daun (Aphis gossypii). J. Agron. Indonesia 46:290-297. Doi:https://doi.org/10.24831/jai. v46i3.20836.

Rout, G.R., S. Sahoo. 2015. Role of iron in plant growth and metabolism. J. Rev. Agric. Sci. 3:162-170. Doi: https://doi.org/10.7831/ras.3.1.

Samik, P. Setiarso, I.G.M. Sanjaya. 2017. Pemanfaatan air buangan $\mathrm{AC}$ (air conditioner) sebagai pengganti akuades. Indonesian Chem. Appl. J. 1:1-7. Doi: https://doi.org/10.26740/icaj.v1n1.p29-36.

Samota, R., B. Jat, S.K. Choudhary, S. Khinchi, B.L. Naga. 2017. Effect of nitrogen sources on whitefly (Bemisia tabaci Genn) in chilli (Capsicum annuum L). J. Pharmacogn. Phytochem. 6:190-193.

Shaban, H., B. Fazeli-Nasab, H. Alahyari, G. Alizadeh, S. Shahpesandi. 2015. An overview of the benefits of compost tea on plant and soil structure. J. Adv. Biores. 6:154-158. Doi:https://doi.org.10.15515/ abr.0976-4585.6.1.154158. 
Saijo, Y., E.P. Loo. 2019. Plant immunity in signal integration between biotic and abiotic stress responses. J. New Phytologist. 225:87-104. Doi:https://doi.org/ 10.1111/nph.15989.

Sitohang, M.C., R. Sipayung, Charloq. 2020. Aplication and response two different calcium nutrient treatment on sweet corn growth (Zea mays saccharata Strutt.) in Ultisol. J. Agroecotech. 8:171-176. Doi:https://doi. org/10.32734/jaet.v8i3.652.

Sopialena. 2017. Segitiga Penyakit Tanaman in Susilo (Eds.). Mulawarman University Press. Samarinda.

Subagyo, V.N.O., P. Hidayat. 2014. Neraca kehidupan kutukebul Bemisia tabaci (Gennadius) (Hemiptera: Aleyrodidae) pada tanaman cabai dan gulma babadotan pada suhu $25^{\circ} \mathrm{C}$ dan $29^{\circ} \mathrm{C}$. J. Entomologi Indonesia 11:11-18. Doi:https://doi.org/10.5994/ jei.11.1.11.

Sun, Y., M. Wang, L.A.J. Mur, Q. Shen, S. Guo. 2020. Unravelling the roles of nitrogen nutrition in plant disease defences. Int. J. Mol. Sci. 21:572. Doi: https://doi.org/10.3390/ijms21020572.

Tahat, M.M., K.M. Alananbeh, Y.A. Othman, D.L. Leskovar. 2020. Soil health and sustaibable agriculture. J. Sustainable 4859:1-26.

Tiswan, D. Ramlan. 2018. Pemanfaatan air buangan air conditioner (AC) sebagai air bersih di kampus 7 Poltekkes Kemenkes Semarang tahun 2017.
Bul. Keslingmas. 37:500-505. Doi:https://doi. org/10.31983/keslingmas.v37i4.3802.

Val-Torregrosa, B., M. Bundó, B.S. Segundo. 2021. Crosstalk between nutrient signalling pathways and immune responses in rice. J. Agriculture. 11:747. Doi:https://doi.org/10.3390/agriculture11080747.

Wahjudin, U.M. 2006. Pengaruh pemberian kapur dan kompos sisa tanaman terhadap aluminium dapat ditukar dan produksi tanaman kedelai pada tanah vertic hapludult dari gajrug, Banten. J. Agron. Indonesia 34:141-147. Doi: https://doi.org/10.24831/ jai.v34i3.1293.

Weinmann, M., V. Romheld, D. Huber. 2012. Mineral Nutrition of Higher Plants $3^{\text {rd }}$ edition. p. 1-649. In Petra, M (Eds.). Elsevier Academic Press.

Yusuf, F., A. Rauf, A. Halid. 2018. Strategi pengembangan cabai rawit di Kecamatan Dungaliyo, Kabupaten Gorontalo. Agrinesia. 2:132-144.

Zhong, J.J. 2011. Plant secondary metabolites. p. 324333. In Moo-Young, $\mathrm{M}$ (Eds.). Comprehensive Biotechnology $3^{\text {rd }}$ edition. Netherlands. Doi:https:// doi.org/10.1016/B978-0-444-64046-8.00169.

Zulfidah. 2018. Populasi Aphis gossypii pada beberapa varietas tanaman cabai rawit. Skripsi. Departemen Hama dan Penyakit Tumbuhan. Fakultas Pertanian. Universitas Hasanuddin. 